UDC 8812.82.087.5

DOI https://doi.org/10.32838/2663-6069/2020.3-3/13

Pukaliak M. .

Lviv Polytechnic National University

\title{
MULTIMODALITY AS THE MEANS OF MEANING CREATION IN ENGLISH FAIRY TEXT AS FICTIONAL LITERATURE
}

The article explores the investigation of the ways we try to get to know the world and ourselves in relation to our settings and environment, we have used and continue to use the fairy tale as figurative mode of communication. For centuries we have developed the oral and literary capacity within our brain to communicate relevant information about specific conditions and relations in our lives and to use and change this information as we get used to our changing conditions.

There is a domain within our brain that enables us to form and conceptualize the information according to variable linguistic trends and developments, and we have developed a strong genetic disposition to forming and cultivating mental and public representations within social and cultural institutions that make the fairy tale relevant as a literary genre that is analyzed in reference to fictional discourse within the framework of cognitive linguistic paradigm.

The fairy tale developed out of an oral cognitive mode of communication and narration which later continued and expanded by print enabling it to acquire the corresponding type of discourse, known as a fictional discourse, fairy tale discourse being one of it.

Fairy tale discourse is a complex linguo-semiotic phenomenon, a product of speech and thought of an ethnic group manifested in different genres of fairy works of art (fairy tales, legends, nursery tales, historical and local tales) together with extralinguistic factors. The works of art that make up fairy tale discourse are united by the common category of fabulousness with the miraculous as its central component and accumulate mythological beliefs shared by society in the system of verbal and nonverbal signs. We consider the place of a fairy tale within the framework of fictional literature and highlight structurally-compositional model, lexico-semantic content and iconic loading of English fairy texts as the examples of multimodal units of narration.

Key words: fairy tale, discourse, cognitive, extralinguistic, paradigm, category.

Formulation of the scientific problem. The rapid development of the latest digital technologies, its total integration into the communication process raises the question of the multimodal nature of communication. Recently, more and more attention is focused on the intermedial or multimodal parameters of the communication flow, while in the communicative space there is 'a general tendency to aesthetize, to illustrate and to visualize various texts as communicative artifacts'.

Analysis of the latest investigations of the question. Researchers emphasize on the high degree of integration of various semiotic resources in the modern communicative process, when it is almost impossible to separate its verbal component from paraverbal one. Paraverbal refers to how we say the words we say, for example do we seem happy, sad, angry, determined or forceful. Some researchers suggest it accounts for about 30\% of what we communicate. Tone of voice and the way in which we choose our words is important here. When we are angry, we tend to speak more rapidly and at a higher pitch. If we feel someone is attacking us, we tend to respond in short, curt, sentences. You can usually tell if a person is bored by a tendency towards a slow and monotone delivery. So, in such a case, discourse is like a polycodal unity, which necessitates the research of parameters of the interaction of verbal and other semiotic codes in the process of discourse creation.

Many scholars try to give a definition to multimodal discourse. Van Leeuwen points out that 'multimodality' means the combination of different semiotic modes - for example, language and music in a communicative artifact or event. For example, language and music - in a communicative artifact or event. It also refers to the diverse ways in which a number of distinct semiotic resource systems are both codeployed and co-contextualized in the making of a text-specific meaning. A more specific definition is that "multimodal discourse involves the interaction of multiple semiotic resources such as language, gesture, dress, architecture, proximity lighting, movement, gaze, camera angle, and so on". 
Setting objectives. The main task is to consider the place of a fairy tale within the framework of fictional literature and highlight structurally-compositional model, lexico-semantic content and iconic loading of English fairy texts as the examples of multimodal units of narration.

Presentation of the basic material. In modern linguistics we can see growing interest to the problems of the narrative as an all-embracing element of artistic text, capable of manifestation of the features of the genre, style and author's positions. Modern fiction represents a complex synthesis of comprehension and the embodiment of the features of the author's artistic concept and his worldview.

In the basis of modern literary process lies the idea of stylistic eclecticism and, consequently, the style reorganization of the formed speech forms. So in the British literature we observe "the transformation of previously created artistic forms: words, character, plot, chronotope, genre' [1, p. 56-59].

Eclectisism means a combination in one work the signs of different styles, a combination of diverse artistic elements. Such a symbiosis of styles can be observed not only in literature, but in painting, music, architecture, interior design.

Speaking of eclecticism as a stylistic principle of British literature, we mean the diversity and breadth of text formation. Eclecticism as a stylistic property of fairy exposes the essential features of its poetics and also explains the relationship of the text with the non-textual reality.

In a fairy text means of eclectic combinations of the semantic parts of a text we can observe the connection between myth and reality, everyday and eternal, rational and irrational. In fiction, as the model of complex objective-subjective world, the reflection of system of modern world is observed and realised with the help of various narrative methods.

'Writing, image and colour lend themselves to doing different kinds of semiotic work; each has its distinct potentials for meaning - image may just have the edge over writing' $[2, \mathrm{p} .1]$. The starting point for social semiotic approaches to multimodality is to extend the social interpretation of language and its meanings to the whole range of modes of representation and communication employed in a culture. Central to this approach are three theoretical assumptions.

Social semiotics assumes that representation and communication always draw on a multiplicity of modes, all of which contribute to meaning.
It focuses on analyzing and describing the full repertoire of meaning-making resources which people use in differently realized in different modes. For instance, the spatial extent of a gesture, the intonational range of voice, and the direction and length of a gaze are all part of the resources for making meaning. The meanings of multimodal signs fashioned from such resources, like the meanings of speech, are located in the social origin, motivations and interests of those who make the sign in specific social contexts. These all affect and shape the sign that is made. The meanings realized by any mode are always interwoven with the meanings made with those other modes co-present and co-operating in the communicative event. This interaction produces meaning. Multimodality focuses on people's process of meaning making, a process in which people make choices from a network of alternatives: selecting one modal resource, meaning potential, over another.

In the opinion of H. Stockl multimodal approach rises the status of multimodal semiotics, as methodological apparatus of this branch can be applied to the analysis of heterogeneous nonverbal modes, which go far beyond scientific tasks of traditional linguistics and semiotics of a text. It is worth to mention than multimodality is a relatively new discipline and it has got whole number of theoretical questions. The first and the most important is to provide a definition of the object of the research - to the mode of communication.

First of all, communication is interpreted as transmission of meanings, which is going on several regimes/plans/modes of communication especially in oral and written speech. The chose and arrangement of these modes of communication separately or in interaction makes it possible to generation and transmission of meanings in the process of communication. Secondly, transmission of meanings is happening because of involvement of heterogeneous semiotic (lingual and paralingual) and sensory-perceptual (smell, taste) resources. The last but not least, affirmations about multimodal character of communication and multimodality as property of all texts without any conclusions, even those who seems to be mono-modal are axiomatic. Traditionally, the term 'text' has been used to refer 'mono- modally' to verbal text. However, according to Kress and van Leeuwen "all texts are multimodal, meaning that all texts always and without exception involve the interaction and integration of several semiotic modes' [2, p. 2]. Therefore in making sense of the multimodal texts, moving beyond the traditional cognitive strategies and enhancing the readers' 
interpretive abilities is an important part of reading comprehension instruction. Images and texts are being combined in unique ways, and readers in today's world need new skills and strategies for constructing meaning in transaction with these multimodal texts as they are encountered during the social practices of interpretation and representation. If visual discourse treats images themselves as agencies, power relations are misconstructed by hiding the responsibility of the users.

A literary work is a textually embodied conceptual structure, whose conceptual component is identical to the structure - compatible with its text - which its author intended (meant) in composing it [3, p. 49].

Among the main aspects of the composition study are problems of complex definition of the term, delineation of external and internal compositions, outlining functional-semantic features of composite parts of texts, etc. Not taking into consideration the cultural scale and historical experience of study, the only approach to the interpretation of this category does not exist at present. Mostly the composition is considered as the form or content phenomenon. The main categories of the text include the form and content categories where the composition is a component of the form category. The concept of composition is interpreted as a form, that systematize, provides integrity. In a dynamic aspect, "the composition is defined as a motivated arrangement components (fragments of the text); in each of them there is a certain way of the image (characteristic, description, dialogue, monologue) or a separate point of view (author, narrator, the character) regarding the depicted." In view of this, the composition ensures unity of a literary work.

The fairy belongs to folk literature and is part of the oral tradition. In its written form the fairy tale tends to be a narrative in prose about the fortunes and misfornrnes of a hero or heroine who, having experienced various adventures of a more or less supernatural kind, lives happily ever after. Magic, charms, disguise and spells are some of the major ingredients of such stories, which are often subtle in their interpretation of human fiature and psychology [4, p. 302].

Narratology in literary theory is the study of narrative structure and principle. It is the study of the logic, principles, and practices of narrative representation.

Narratology studies the form and the technique.

Narratology is devided into:

- order: sequence of events;

- frequency: the separation between an event and its narration that allows several possibilities;
- duration: the discourse time and narrative time, the separation in time between and event and its narration

- voice: narrator, how tells the story;

- mood of writing: mood means the distance of intimacy, mood is defined in the distance and perspective of the narrator;

The structure of a work determines its integrity, completeness and unity [4, p. 302]. Composition of a fairy text is predetermined by author's intentions, genre and content of the literary work. It embodies system of combination of all its elements.

The composition not only provides a syntagmatic sequence of elements of the fairy text, but also participates in the formation of logical connections established between them. It is identified with a network of links between plots covering the entire work. In the context of contemporary research of the composition, were outlined structural criteria of organization of the text such as multiplicity, dynamism and variability [5, p. 32].

The sense of dynamization of the composition is interleaving, changing and stratification of the verbal rows. Due to this, the transformation of the original text material into composite version is happening. The key to transformation is interaction and interpenetration elements of the text. Compositional transformation means to replace actualizators, that is, semantically filled elements that play an important role in the structure of the text. According to the above concept, no element of the text can be positionally fixed in the composition. Its position and functions depend on the selected strategy of interpreting the text.

Literary text serves as a representation of the unique and exclusive artistic world, which is "an independent modal structure" [6, p. 369].

Among the main features of modern fairy, the plurality of options of interpretations is determined. Fairy text has inexhaustible interpretation potential and infinite plurality of meanings that create an open literary work. So, compositional structure of the fairy text is considered as a formal organization of its elements in a particular syntagmatic sequence or hierarchical dependence. From the point of view of informativity compositional components are not homogeneous, since the most important information is concentrated preferably in strong text positions.

When taking into consideration the compositional structure of the text portions, size, fragments, integrity, functional specificity are distinguished. These aspects are taken into account in formocentric and content approaches to defining the concept of composition. However, in conditions of the modern process of text 
formation we should take into account the following structural principles of organization such as dynamism, variability, plurality. This is connected with traditional for postmodernism conception of an open literary work.

"If narrative purpose, coherence, rationality are founded on and speak the notion of integral selfhood, then vagueness, indirection and ambigious symbolisation express awareness of self-fragmentation" [7, p. 89].

Two types of textual connectivity are identified cohesion and coherence. Cohesion (local connectivity) is "a connection of a linear type that has formal expression mainly with the help of linguistic means" [5, p. 51]. It is based on the pronoun substitutions, lexical repetitions, use of conjugations, correlation of grammatical forms. It is hard to find reasons to believe that the position the author should assume for himself is one in which he is a provider of often incoherent thoughts and feelings regarding how he experiences life and reality, rather than the more traditional position in which the author tells a story with characters and their acts being the main focus.

Unlike cohesion, coherence (global connectivity) is the connectivity of a non-linear type that combines elements of different levels of text. The most important means of providing coherence include repetitions of words with common semantic components and parallelism. In fiction there may be semantic chains - rows of words with common sema. Their interaction provides the generation of new semantic ties, relationships. "Deploying semantic rows (chains), their location and relationship determine the semantic composition of the text" [5, p. 52].

But, as has been frequently noted in the literature, cohesion does not of itself lead to the realization of a text as a coherent discourse. "Identifying cohesive links by noticing how semantic features are copied across different items and how items act upon each other by the modification principle will narrow down the pragmatic possibilities, but cannot determine interpretation" [8, p. 131].

Dirk Geeraerts studied lexical fields, various types of their relations and methods of the analysis. He distinguished lexical, semantic and conceptual fields of the words. Along with him, Geoffrey Leech and John Lyons studied meanings of the words, phrases and sentences and their diverse types differentiating conceptual, connotative, emotive and other meanings.

Humans don't use words without any intentions, either explicit or implicit. The meaning of the words can be lexical or cognitive, have logical or denotative content sense, be based on associations or conceptual structures. So, dealing with meaning of the words, we are talking about semantics that is "the study of meaning system of a language, so it concerns the meaning of words" [9, p. 46-47].

The word 'semantic' was introduced by Michel Breal during the 19th century. According to John I. Saeed, semantics is "a study of meaning communicated through language. It has been observed a great interest in semantic theory among linguists in the last few years" [10, p. 69]. The main reason is the development of generative grammar that emphasizes on the distinction between deep structure and surface structure. On the one hand, semantics deals with the way words and sentences are related to objects and processes in the world. On the other hand, it deals with way words are related to each other in terms of synonymy, entailment and contradiction. "Social-semiotic theory is interested in meaning in all its forms. Meaning arises in social environments and in social interactions. The core unit of semiotics is the sign, a fusion of form and meaning".

Lexical semantics concerned with the identification and representation of the semantics of lexical items. Lexemes are linguistic items with their own meanings that cannot be predicted based on the meaning of the parts and can be considered from different perspectives. The meaning of content words is concepts that correspond to concrete objects with definite properties.

According to G. Leech, there are such types as 'associative meaning' and 'conceptual meaning.' Firstly, conceptual meaning, logical or cognitive is stylistically neutral and objective; it is basic propositional meaning which corresponds to the primary dictionary definition. Geoffrey Leech has defined conceptual meaning as "the widely assumed to be the central factor in linguistic communication" [9, p. 49].

Conceptual meaning deals with the core meaning of the expression and has the aim of providing an appropriate representation to a word or sentence. Associative meaning is subjective and stylistically marked. In terms of it five types of meaning can be distinguished. Connotative meaning manifests itself in associating an expression or word with one's experience or viewpoint adopted by individual, group or society. Stylistic meaning is conveyed about 'the social context and stylistic features' of the piece of language used by the writer. Mainly stylistically marked lexical items and expressions can be encountered in the texts of the book jackets, especially in the book reviews that bear features of publicistic and colloquial styles (kick-butt, drop-dead, poignant, heart-stopping, captivating) and in the blurbs that 
have features of publicistic and belles-lettres styles (the plot thickens, the voyage of a lifetime, sheds light on this enduring mystery, the greatest epic fantasy, awardwinning).

Adrienne Lehrer defined a semantic field as a set of lexemes which cover a certain 'conceptual domain' and which bear certain specifiable relations to one another. The advantage of a semantic field is that it gives you an overview of a conceptual area and allows you to see how different 'linguistically coded concepts' in a language determine each other.
Conclusions. Fairy tale discourse is a complex linguo-semiotic phenomenon, a product of speech and thought of an ethnic group manifested in different genres of fairy works of art (fairy tales, legends, nursery tales, historical and local tales) together with extralinguistic factors. The works of art that make up fairy tale discourse are united by the common category of fabulousness with the miraculous as its central component and accumulate mythological beliefs shared by society in the system of verbal and nonverbal signs.

\section{References:}

1. Бехта I. А., Карп М. А. Мультимодальні засоби когезії та когерентності у сучасних літературних казках: теоретико-методологічна інтерпретація. Науковий вісник Міжнародного гуманітарного університету. Серія «Філологія». 2014. Вип. 13. С. 88-108.

2. Kress G. The Routledge Handbook of Discourse Analysis. London : Routledge, 2011. 712 p.

3. Mitchell K. Intention and Text Towards an Intentionality of Literary Form. New York : Continuum, 2008. 192 p.

4. The Penguin Dictionary of Literary Terms and Literary Theory / ed. by J. A. Cuddon. England : Penguin Books, 1999. 1024 p.

5. Hoey M. Textual interaction: An introduction to written discourse analysis. London; New York : Routledge, 2001. 224 p.

6. Enkvist N. E. From Text to Interpretability: A Contribution to the Discussion of Basic Terms in Text Linguistics. Connexity and Coherence: Analysis of text and Discourse. New York : Walter de Gruyter \& Co, 1989. 382 p.

7. Brown D. The Modernist Self in Twentieth-Century English Literature: A Study of Self-Fragmentation. Hampshire; London : The Macmillan Press Ltd., 1989. 206 p.

8. Widdowson H. G. Text, Context, Pretext.Critical Issues in Discourse Analysis. Cornwall : Blackwell Publishing Ltd, 2004. 200 p.

9. Leech G. Semantics: The study of meaning. London : Penguin books, 1974. 400 p.

10. Saeed J. Semantics. Australia : Wiley Blackwell, 2003. 480.

\section{Пукаляк М. В. МУЛЬТИМОДАЛЬНІСТЬ ЯК ЗАСІБ СТВОРЕННЯ АНГЛІЙСЬКОГО КАЗКОВОГО ТЕКСТУ ЯК ХУДОЖНЬОЇ ЛІТЕРАТУРИ}

Стаття досліджує способи, якими ми намагаємося пізнати світ $і$ нас самих стосовно наших обставин і середовища, де ми використовували та продовжуємо використовувати казку як образний спосіб спілкування. Протягом століть ми розвивали усну й літературну здатність нашого мозку передавати відповідну інформацію про конкретні умови та стосунки в намому житті, змінювати цю інформачію, коли ми звикаємо до мінливих умов.

У нашому мозку є ділянка, яка дає нам змогу формувати й осмислювати інформацію відповідно до змінних мовних тенденцій і розвитку, $і$ ми розробили сильну генетичну схильність до формування та культивування психічних і громадських уявлень у соџіальних і культурних установах, що створюють казку як актуальний літературний жанр, який аналізується у зв'язку з вигаданим дискурсом у рамках когнітивної лінгвістичної парадигми.

Казка розвинулася з усного когнітивного способу спілкування й розповіді, який згодом продовжився та розширився завдяки друку, що дало їй змогу набути відповідного типу дискурсу, відомого як вигаданий дискурс, одним із яких є казковий дискурс.

Казковий дискурс-ие складне лінгвосеміотичне явище, продукт мовлення та думки етнічної групи, що проявлясться в різних жанрах казкових художніх творів (казки, легенди, дитячі казки, історичні й місиеві казки) разом із екстралінгвістичними факторами. Художні твори, щчо становлять казковий дискурс, об'єднані загальною категорією казковості з чудотворним і иентральним компонентом, які накопичують міфологічні вірування, спільні для суспільства в системі вербальних і невербальних знаків. Ми розглядаємо місие казки в рамках художньої літератури та виділяємо їх структурно-композииійну модель, лексико-семантичний зміст і знакове завантаження англійських казкових текстів як приклади мультимодальних одиниць переказу в тексті.

Ключові слова: казка, дискурс, когнітивний, екстралінгвістичний, парадигма, категорія. 